\title{
The Mantle Plume Debates
}

\author{
Xueping Li \\ Geology and Geophysics Department, Missouri University of Science and Technology, Rolla, USA \\ Email: lixueping12321@163.com
}

How to cite this paper: Li, X.P. (2018) The Mantle Plume Debates. Open Journal of Yangtze Gas and Oil, 3, 147-152.

https://doi.org/10.4236/ojogas.2018.32013

Received: January 7, 2017

Accepted: April 25, 2018

Published: April 28, 2018

Copyright (C) 2018 by author and Scientific Research Publishing Inc. This work is licensed under the Creative Commons Attribution International License (CC BY 4.0).

http://creativecommons.org/licenses/by/4.0/

\begin{abstract}
We all know that most volcanic activities occur at the plate boundaries because some deformations take place on plate margins. However, some volcanoes are found in oceans which are not plate margins and always form liner islands and seamount, such as the Hawaiian Emperor chain in the Pacific. So, we would consider why they are different from other normal volcanic activities, and we are also interested in the reasons for their formation. In addition, we are also curious about the relationship between island chains and plate motions. According to a lot of researches, scientists suggest a hypothesis that hotspots are the origination of island chains. And the hotspots are identified to originate from mantle plumes. Herefrom, mantle plumes become the focus of discussion, and at the same time, some geological structures extending from mantle plumes are also used as the research objects, like large igneous plumes (LIPs), Large low-shear velocity provinces (LLSVP's), mid ocean ridge basalt (MORB), ocean island basalt (OIB), plate motions, extensive of major mantle plumes, and so on. The above topics will be discussed in this paper. There are some controversies over mantle plumes because some facts are in contradiction to the theory of mantle plumes, which will also be talked about.
\end{abstract}

\section{Keywords}

Mantle Plume, Hotspots, Plate Motion

\section{Introduction}

About mantle plumes, there are a lot of definitions, two of which are in the majority. One is W. J. Morgan's original definition of a mantle plume-a thin, hot column of mantle material moves up the core-mantle boundary. And he also called them the mantle source "hotspots" that rose from the lower mantle that made the overlying lithosphere thinned [1]. The other one is from Anderson who proposed that plumes involved high temperature, great depth, rapid 
upwelling and a mechanism that involved bottom heating of an isothermal homogeneous fluid [2].

In addition, when talking about mantle plumes, we also mention the following geological structures which have a relationship with plumes. This paper will illustrate relevant conceptions of large igneous provinces (LIPs), large low-shear velocity provinces (LLSVP's), mid-ocean ridge basalt (MORB) and ocean island basalt (OIB).

Besides, Anderson thought that the upwelling from a long-isolated and more primitive reservoir often caused high $4 \mathrm{He} / 3 \mathrm{He}$ or $21 \mathrm{Ne} / 22 \mathrm{Ne}$ ratios of hotspot lavas [3]. Therefore, as hotspots igneous rocks and igneous rocks are associated with normal volcanoes, some differences appear. As we know, igneous rocks congregate crystal minerals from molten material in the earth's mantle. They often have two types, intrusive rocks and extrusive rocks. Nonetheless, the composition of hotspots igneous rocks is more complex. The lower parts of these volcanic rocks are formed by tholeiitic basalt, while the upper parts are formed by alkali basalts which are affluent in $\mathrm{Na}$ and $\mathrm{K}[4]$.

\section{Concept of Geological Structures with Mantle Plumes}

\subsection{Large Igneous Provinces}

Large igneous provinces (LIPs), which represent anomalously high magmatic fluxes, create from processes other than "normal" seafloor spreading and they are formed by intrusive rock and extrusive rock, both of which are rich in $\mathrm{Mg}$ and $\mathrm{Fe}$ [5]. Some basaltic volcanisms which do not happen at plate boundaries and probably from mantle plumes, like continental flood basalts and giant oceanic plateaus, can cover large areas. Sometimes those volcanic activities form LIPs.

\subsection{Large Low-Shear Velocity Provinces}

Large low-shear velocity provinces (LLSVP's) respect the largest shear wave velocity gradient. These two provinces have a certain association. Austermann et al. supported that statistical tests would show a significant correlation between the location of LIPs and the margins of LLSVPs if plumes were generated randomly throughout region of slower-than-average shear wave velocity in the deep mantle [6].

\subsection{Mid-Ocean Ridge Basalt and Ocean Island Basalt}

As is known that volcanic activities would produce a lot of volcanic rocks that have rare gas isotopic. So the concepts of Mid-ocean ridge basalt (MORB) and ocean island basalt (OIB) are associated with geochemical signature. MORB is a type of tholeiitic basalt that shows a lowering of the ratios for the light rare-earth elements (LREEs). Whereas, ocean island basalt (OIB) depends more on $\mathrm{Pb}$ isotope ratios [7]. 


\section{Mantle Plumes and Hotspots}

\subsection{The Number of Plumes}

How many plumes are there all over the world? Anderson and Natland pointed that the number of plumes rises from the original about 20 to as many as 5200 for the number of moderate-size plumes [2]. And there are about 7 primary plumes that come from the D' region above the core-mantle boundary, Iceland, Tristan da Cunha, Afar, Reunion, Hawaii, Louisville, and Easter. So how to infer mantle plumes from surface observations? The main method is the distribution of hotspots. According to the definition of hotspots, they represent the surface of mantle plumes. Therefore, the distribution of mantle plumes can be shown by hotspots (Figure $1[8]$ ).

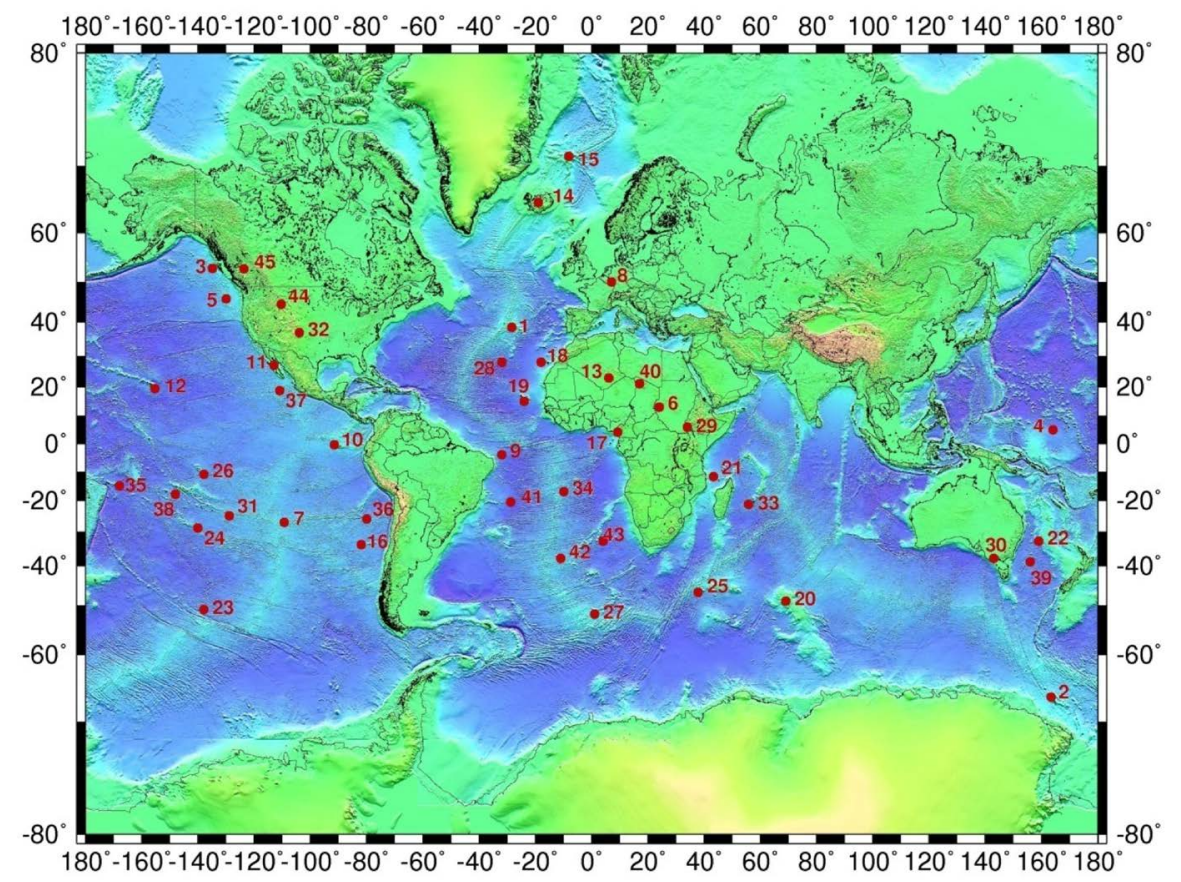

Figure 1. Global distribution of hotspots.

\subsection{Detecting Plumes}

How can plumes be detected, that is, what are the technological tools to detect them? Some scientists use seismic waves because plumes always have lower density than surrounding rocks. Lower density means the lower seismic velocity. Thus, if the velocity contrast is large enough or the plume diameter is several times larger than the wavelength of the seismic waves, a plume can be detected. Seismic tomography is a major tool to detect the structure of mantle plumes. Above all, the reasons for detecting plumes by using seismic waves are shown below. 1) The velocity contrast is large enough. 2) The plume diameter is several times larger than the wavelength. 3) There is a sufficient number of seismic rays going through the plume. 4) Seismologists have developed AND that is a right tool to detect. 5) The computers are powerful enough to perform the huge 
amount of modeling and data analysis job. From the research of Montelli et al., the maximum depth of shallow plumes is $100 \mathrm{~km}$ and deep plumes are from the core-mantle boundary [9]. Because of the small velocity contrast and small diameter, the depth of extent of the columns is poorly constrained.

\section{Plate Motion}

Morgan proposed that hotspots are manifestations of convection in the lower mantle provides the motive force for continent drift because asthenosphere currents flowing radically away from each of these plumes can generate stress to move plates [1]. In his opinion, this is based on following observations. 1) Most hotspots are located near rise crest or each of the ridge triple junctions. 2) Hotspots become active before continents split apart. 3) Hotspots are not just surface volcanism. 4) Both rises and trenches do not drive the plates. Therefore, hotspots tracks represent the chains of islands and seamounts extending away from active volcanic hotspots. For example, well-known is the Hawaiian Emperor chain which is $6000 \mathrm{~km}$ long in the southeast to extinct. Morgan also supported that fixed hotspots which means that volcanic hotspots do not move relative to each other. So the mantle plumes remain stationary and plates move over them. Based on fixed hotspot assumption, the plate motions over the mantle are determined for the past $200 \mathrm{Ma}$. So far, there are about 40 hotspots being accepted around the world.

\section{Controversies}

Although it seems reasonable to explain volcanoes which do not erupt at the plate boundaries, there are also a lot of controversies over the presence of mantle plumes.

\subsection{Fixed or Active Hotpots}

First of all, we all know that Morgan pointed that volcanic hotspots do not move relatively to each other because he thought that the viscosity of lower mantle is very high so that it would be immobile, and this provided the fixed hotspots reasonably [10]. However, in the modern view, the lower mantle has a moderate viscosity and its convection is quite active. So it is unclear to say that hotspots are fixed. From this controversy, whether mantle plumes are fixed or moving slowly is a problem to discuss. In addition, from the results of former discussions, like Hawaiian hotspots, the hotspots tracks usually allow the straight chain. Conversely, some hotspots tracks do not show a simple line chain but seem more complicated so that it is difficult to measure their age progression and plate motions. Nevertheless, most scientists approve the mantle plumes theory because they are more accurate and useful to explain many geological phenomena.

\subsection{Future Work}

Mantle plumes are not only controversial topics, but also have some unsolved 
problems for future work. The first one is temperature. For example, we know that mantle plumes are usually hotter than normal plumes because they could rise from lower mantle. However, according to Gao and Liu's research, Yellowstone is not associated with higher temperature than that of normal mantle transition zone (Figure 2) [11].

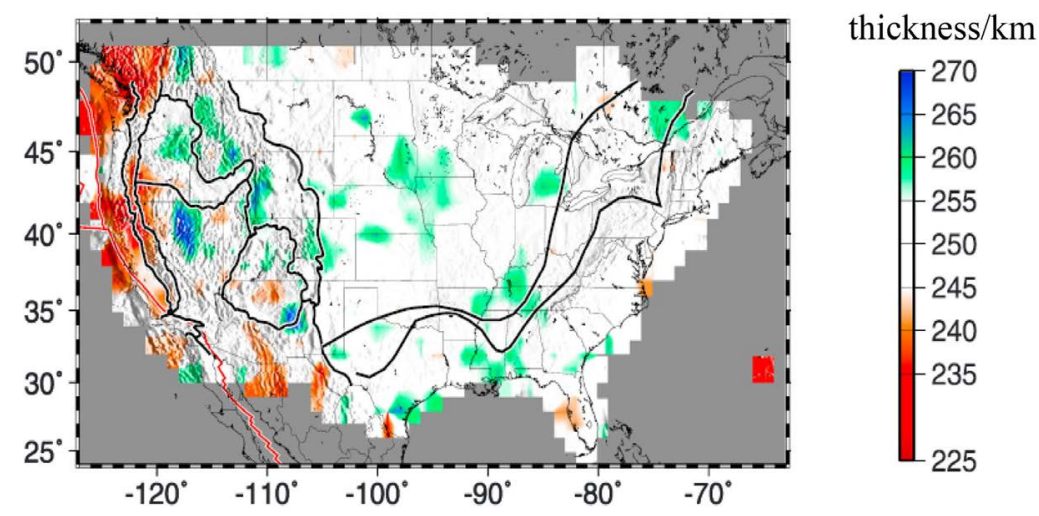

Figure 2. MTZ thickness.

Similarly, some scientists thought that the Baikal rift zone in Siberia relates to a mantle plume. Yet Liu and Gao suggested that this mantle transition zone beneath the Baikal rift zone is not hot [12]. Therefore, it is hard to explain the mantle plumes have anomalous temperature and we should examine it more. From Anderson [2], although Hawaii is considered to be a plume, some studies pointed out that the lithosphere under Hawaii would be thinned because of plume heating, but it is not yet clear whether this condition was before the magmatism or a result of it. Large volumes of melt can be both from fertile mantle and hot mantle particularly. So it still needs to be researched in the future. In addition, due to the difference of continental and oceanic hotspots, there is a lack of continental hotspots. So the scientists need to search more evidences to find continental hotspots.

\section{Conclusion}

In conclusion, although there are a lot of evidences of mantle plumes, it does not mean that everyone believes that. However, scientists insist on researching them and have provided more information and knowledge about mantle plumes. In this paper, I introduced the definition of a mantle plume proposed by Morgan and others, the number of plumes from various studies, the relationship between LLSVP's and plumes, the relationship between LIPs and plumes, the differences between hotspot igneous rocks and igneous rocks associated with normal volcanoes, and the results of seismological investigations of the depth extension of major mantle plumes. Besides, I also talked about the traces of hotspots and plate motion. Nevertheless, some of them are still controversial. However, I still believe that the evidences of mantle plumes are effective. It is useful to prove the plate motion. Therefore, we should believe that we would make more advances 
about the mantle plumes.

\section{Acknowledgements}

I am grateful to thank to Dr. Stephen Shangxing Gao who is the professor of geophysics.

\section{References}

[1] Morgan, W.J. (1971) Convection Plumes in the Lower Mantle. Nature, 230, 42-43. https://doi.org/10.1038/230042a0

[2] Anderson, D.L. and Natland, J.H. (2005) A Brief History of the Plume Hypothesis and Its Competitors: Concept and Controversy. Special Paper 388: Plates, Plumes and Paradigms, 119-145. https://doi.org/10.1130/0-8137-2388-4.119

[3] Anderson, D.L. (1998) The Helium Paradoxes. Proceedings of the National Academy of Sciences, 95, 4822-4827. https://doi.org/10.1073/pnas.95.9.4822

[4] Karl, D.M., McMurtry, G.M., Malahoff, A. and Garcia, M.O. (1988) Loihi Seamount, Hawaii: A Mid-Plate Volcano with a Distinctive Hydrothermal System. Nature, 335, 532-535. https://doi.org/10.1038/335532a0

[5] Coffin, M.F. and Eldholm, O. (1994) Large Igneous Provinces: Crustal Structure, Dimensions, and External Consequences. Reviews of Geophysics, 32, 1. https://doi.org/10.1029/93RG02508

[6] Austermann, J., Kaye, B.T., Mitrovica, J.X. and Huybers, P. (2014) A Statistical Analysis of the Correlation between Large Igneous Provinces and Lower Mantle Seismic Structure. Geophysical Journal International, 197, 1-9. https://doi.org/10.1093/gji/ggt500

[7] Armienti, P. and Gasperini, D. (2007) Do We Really Need Mantle Components to Define Mantle Composition? Journal of Petrology, 48, 693-709. https://doi.org/10.1093/petrology/egl078

[8] Wölbern, I. https://commons.wikimedia.org/wiki/File:Hotspots.jpg

[9] Montelli, R. (2004) Finite-Frequency Tomography Reveals a Variety of Plumes in the Mantle. Science, 303, 338-343. https://doi.org/10.1126/science.1092485

[10] Morgan, W.J. (1968) Rises, Trenches, Great Faults, and Crustal Blocks. Journal of Geophysical Research, 73, 1959-1982. https://doi.org/10.1029/JB073i006p01959

[11] Gao, S.S. and Liu, K.H. (2014) Mantle Transition Zone Discontinuities Beneath the Contiguous United States. Journal of Geophysical Research: Solid Earth, 119, 6452-6468. https://doi.org/10.1002/2014JB011253

[12] Liu, K.H. and Gao, S.S. (2006) Mantle Transition Zone Discontinuities Beneath the Baikal Rift and Adjacent Areas. Journal of Geophysical Research: Solid Earth, 111. https://doi.org/10.1029/2005JB004099 